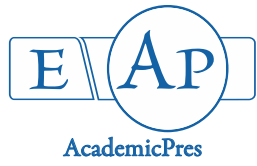

\title{
Effect of Lasiodiplodia pseudotheobromae Isolates, a Potential Bioherbicide for Amaranthus hybridus L. in Maize Culture
}

\author{
Charles Oluwaseun ADETUNJI ${ }^{1 *}$, Julius Kola OLOKE ${ }^{2}$, \\ Gandham S. PRASAD ${ }^{3}$, Isaac Oluseun ADEJUMO ${ }^{4}$ \\ ${ }^{1}$ Landmark University, Microbiology Unit, Applied Microbiology, Biotechnology and Nanotechnology Laboratory, Department of Biological \\ Sciences,PMB 1001,Omu Aran, Kwara State,Nigeria; charliguitar@yahoo.com; adetunjicharles@gmail.com (*corresponding author) \\ ${ }^{2}$ Ladoke Akintola University of Technology, Department of Pure and Applied Biology, PMB 4000, \\ Ogbomoso,Oyo State, Nigeria; Jkoloke@yahoo.co.uk \\ ${ }^{3}$ Institute of Microbial Technology, Department of Molecular Biology, Sector 39A, Chandigarh, India; prasad@imtech.res.in \\ ${ }^{4}$ Federal University, Department of Animal Science, Animal Nutrition, Biotechnology and Food Safety Laboratory, \\ Gashua, Nigeria; smogisaac@gmail.com
}

\begin{abstract}
The use of phytopathogenic fungi in biological control of weeds may represent a promising alternative to the use of chemicals and may lead to the sustainability of agro-ecosystems. In the current study, strain C1136 was developed into various formulations and their activities were compared with a chemical herbicides using glyphosate in a screen house, applying standard procedure. All the bioherbicide treatments gave significantly higher yield component on the following parameters: tasselling, number of cobs, day of silking, number of ears, number of grain/cob, weight of 100 grains, number of cob, weight of cob, and length of cob from maize when compared to the chemical-treated herbicides and weedy cheek. Moreover, the bioherbicidal formulation coded BH4 (32 g of semolina $+6 \mathrm{~g}$ kaolin $+20 \mathrm{~mL}$ of glycerol + mutant strain of Lasiodiplodia pseudotheobromae + glucose + sucrose + fructose + dextrose + lactose sugar + peptone) showed the highest activities when compared to other formulations. Conclusively, this study revealed that Lasiodiplodia pseudotheobromae C1136 strain has bioherbicidal activity and could therefore be exploited for large scale production of bioherbicides for weed control in conventional farming, to improve yield and enhance food security.
\end{abstract}

Keywords: bioherbicides, Lasiodiplodia pseudotheobromae, yield components, weeds, pasta granules

\section{Introduction}

The synthetic pesticides used to control pests may find their way into food chain through residues in grains consumed by man and animals (Maton et al., 2016; Marvel and Sarah, 2016). Hence, there is the need for safe, eco-friendly and effective bio-pesticides. Maize is commonly used as food for man and for feeding livestock, constituting about $50 \%$ of monagastric animal feed. Pests, such as weevils, rodents and weeds are important factors militating against maize cultivation, thereby intensifying the keen competition between man and animals for cereals (Bankole and Mabekoje, 2004; Ofor $e t$ al., 2009). Nigerian agriculture is dependent on the use of synthetic pesticides which has resulted in reduced body weight gain and liver dysfunction in animals (Adejumo et al., 2014; Adejumo et al., 2015). There is an obvious need to source for cheap and safe pesticides through the use of agroindustrial wastes.
The "bioherbicide strategy" is a microbial approach used to control weeds in agronomic crops (Charudattan, 1991). This strategy involves treating weed-infested crops with an inundative application of microbial propagules of highly aggressive, host-specific pathogens of the target weed (Jackson and Schisler, 1995; Jackson et al., 1996). Constraints to the commercial development of these agents include the lack of low-cost production methods, stable microbial formulations with extended shelf life, and consistent weed control under field situations whenever it is applied. The development of lowcost methods for mass producing stable bioherbicidal propagules is a critical step in the commercialization of these products (Bowers, 1982).

Weed control strategies using microbial agents have received considerable attention in recent years due to the mounting expense for registration of chemical herbicides, ban on the use of chemical herbicides and public demands for reduced chemical uses (Auld, 1991; Charudattan, 1991). There is a worldwide resurgence of interest in the use of indigenous ecofriendly and host specific fungal pathogens, as 
132

herbicides (myco-herbicides) and a significant advance in mass production and fermentation of some of them, have been observed (Eilenberg et al., 2001; Adetunji and Oloke, 2013).

Lasiodiplodia pseudotheobromae emerged from a recent separation of cryptic species originally identified as $L$. theobromae (Alves et al., 2008). The species is known from Africa, Europe and Latin America, where it has been described from forest and fruit trees. Growing evidence suggests that $L$. pseudotheobromae, like $L$. theobromae, has a worldwide distribution and a wide host range (Begoude et al., 2010; Mehl et al., 2011).

Amaranthus species are listed among the most herbicide resistance-prone annual broadleaf weeds because of their high genetic variability, high production of rapidly germinating seeds, and efficient pollen and seed distribution (Lovell et al., 1996). Amaranthus species including smooth pigweed (Amaranthus hybridus L.) have been reported to be resistant to ALS-inhibiting herbicides (Heap, 2015). A. bybridus and redroot pigweed (A. retroflexus L.) interference have been studied in a variety of field crops as major weeds that affect the productivity of beans (Phaseolus spp.) (Aguyoh and Masiunas, 2003; Amini et al., 2014; Mirshekari et al., 2014), soybean (Glycine max) (Bensch et al., 2003), corn (Zea mays) (Knezevic et al., 1994; Sheibany et al., 2009; Ghanizadeh et al., 2014) cotton (Gossypium hirsutum) (Buchanan and Burns, 1971; Buchanan et al., 1980) and yield of corn (Knezevic et al., 1995).

The current study aimed to study the screen house evaluation of myco-herbicides from Lasiodiplodia pseudotheobromae against Amaranthus bybridus.

\section{Materials and Methods}

\section{Source and maintenance of fungal isolate}

C1136 strain was isolated from a small chlorotic and necrotic lesions on leaves of Tridax procumbens from Ogbomoso and Ilorin environments. The most active strain showing herbicidal properties from the authors' previous work was coded as "C1136" (Adetunji and Oloke et al., 2013). The inter transcribe spacer D1/D2 region characterization of the bioherbicidal strain identified it as Lasiodiplodia pseudotheobromae with an accession number KY432690. The fungal isolates were incubated on potatoes dextrose agar (PDA) for 7 days at $25 \pm 1{ }^{\circ} \mathrm{C}$ in BOD incubator. At the end of each incubation period, the colonies were sub-cultured onto fresh media maintained on slants of PDA and stored at $4{ }^{\circ} \mathrm{C}$ in the refrigerator.

\section{Exposure of Lasiodiplodia pseudotheobromae to UV light to induce random mutation}

This experiment was carried out in order to observe whether by mutation it can improve the amount of phytotoxic metabolites in the medium. This was carried out by preparation of fresh PDA plate, to grow the organisms. After the growth of the organisms, cork borer was used to obtain several mycelia plugs from the culture into a sterile PDA plate. The sterile plate containing several mycelia plugs were placed under UV lamp at $300 \mathrm{~nm}$ wavelength at a distance of $30 \mathrm{~cm}$ to the plates. At different time interval (30, 60 and 90 minutes), 5 mycelia plugs were withdrawn and used as inoculants. The mycelia plugs from the wild type culture served as the control. The wild strain was coded WLp, while the mutants were coded Lp 30, Lp 60 and Lp 90. The mycelia plugs from the domesticated type culture serve as the control (Adetunji and Oloke, 2013).

\section{Preparation of pastagranules}

The procedures developed by Connick et al. (1991), Adetunji and Oloke (2013) and optimized by Elzen et al. (2004) were used. Thirty-two grams (g) of semolina, a coarse durum wheat flour, $6 \mathrm{~g}$ kaolin, $2 \mathrm{~g}$ sucrose, $20 \mathrm{~mL}$ of fungal inoculum serving as active ingredient and $3 \mathrm{~mL}$ of deionized water were thoroughly mixed in a dish. The dough was then rolled through a small, hand-operated pasta machine (Marcato Model Ampia 150, Padova, Italy) into sheets, which were folded and extruded 10-15 times at different roller gap settings until it became homogeneous. The dough sheets were then extruded, without refolding, at a narrow setting to yield a 1$\mathrm{mm}$ thick sheet. The sheets were then placed on aluminum foil and air-dried at ambient laboratory conditions $\left[28 \pm 2{ }^{\circ} \mathrm{C}, 33 \pm\right.$ $2 \%$ relative humidity $(\mathrm{RH})]$. The dried sheets were grounded in a grinder into granules and sieved to specific sizes (501-2,000 $\mu \mathrm{m})$. Their initial viability was determined by serial dilution method, by plating the different dilution on nutrient agar and potatoes dextrose agar.

The various pasta granules formulated into various bioherbicides were designated as followed:

(a) $\mathrm{BH} 1=32 \mathrm{~g}$ of semolina $+6 \mathrm{~g}$ kaolin $+20 \mathrm{~mL}$ of glycerol + wild strain of Lasiodiplodia pseudotheobromae (WLp) + glucose + sucrose + fructose + dextrose + lactose sugar + peptone

(b) $\mathrm{BH} 2=32 \mathrm{~g}$ of semolina $+6 \mathrm{~g}$ kaolin $+20 \mathrm{~mL}$ of glycerol + mutant strain of Lasiodiplodia pseudotheobromae ( Lp 60)

(c) $\mathrm{BH} 3=32 \mathrm{~g}$ of semolina $+6 \mathrm{~g}$ kaolin + Lasiodiplodia pseudotheobromae (Lp 30) + glucose + sucrose + fructose + dextrose + lactose sugar + peptone

(d) $\mathrm{BH} 4=32 \mathrm{~g}$ of semolina $+6 \mathrm{~g}$ kaolin $+20 \mathrm{~mL}$ of glycerol + mutant strain of Lasiodiplodia pseudotheobromae $(\operatorname{Lp} 90)+$ glucose+ sucrose + fructose + dextrose + lactose sugar + peptone

(e) $\mathrm{BH} 5=32 \mathrm{~g}$ of semolina $+6 \mathrm{~g}$ kaolin $+20 \mathrm{~mL}$ of glycerol + wild strain of Lasiodiplodia pseudotheobromae (WLp)

(f) $\mathrm{BH} 6=32 \mathrm{~g}$ of semolina $+6 \mathrm{~g}$ kaolin $+20 \mathrm{~mL}$ of glycerol + mutant of Lasiodiplodia pseudotheobromae (Lp30)

\section{Screen house parameters}

The screen house parameters were as follows: $29^{\circ} \mathrm{C}$ day temp, $25^{\circ} \mathrm{C}$ night temp, 16-h day length, with 60 to $90 \% \mathrm{RH}$ Supplemental lighting, computer controlled. Soil mix consisted of sterilized top soil. The soil was supplemented with commercial fertilizer (14:14:14, N:P:K). Experimental pots of $20 \mathrm{~cm}$ height were watered daily until germination. After germination, caution was taken not to get water in the whirl of the seedling. Amaranthus bybridus seeds were collected at Nigerian Stored product research institute farm and stored at $5{ }^{\circ} \mathrm{C}$. Immediately after maize planting and at the cotyledon growth stage of maize, pigweed was planted in the same pot with the maize. Dates of weed sowing were selected so that 
emergence times coincided with specific maize growth stages within the time frame of the critical weed-free period (Van Acker et al., 1993). The following parameters were then taken into consideration: weed control per pot, weed dry weight and weed control efficiency. In each container fertilizer was applied at $1.5 \mathrm{~g}$ fertilizer per pot, while the pasta granules were applied at the rate of $1.0 \mathrm{~g}$ granules/pot. The pasta granules were applied when the seedlings were in the cotyledon to first leaf stage. Control pot was treated with pasta granules without fungus.

\section{Procedures for data collection in the screen house}

Data regarding days to emergence was recorded from the date of sowing till when $80 \%$ of the seedlings emerged in each pot. The data on emergence $\mathrm{m}^{-2}$ was recorded from each treated pot accordingly. Silking date was recorded when the silk became visible on the topmost ear of at least $50 \%$ of the plants in pots. The number of days from planting to silking was then expressed as days to silking. Days to tasseling were observed by counting the number of days from sowing till when $80 \%$ of the plants produced tassels and silks in each pot. Plant height was recorded at the time of physiological maturity from bottom to top excluding tassel. Number of ears plant ${ }^{-1}$ was noted by counting the number of ears in three central rows and were then averaged. The ears harvested from randomly selected plants in each pot were dried and shelled. Number of grains ear ${ }^{-1}$ was counted in selected the thousand grain weights were taken on randomly selected shelled ears of each pot and then their average weight was recorded. Data regarding fresh and dry weight of weed biomass was recorded $26 \mathrm{~d}$ after sowing. After recording the fresh weight, weed samples were oven dried at $80{ }^{\circ} \mathrm{C}$ for $24 \mathrm{~h}$ and re-weighed for dry weight. The leaf area index (LAI) is the ratio of leaf area per plant to the area occupied by the plant. The assay was carried out in triplicates.

\section{Results}

\section{Effect of the different formulated bioherbicides on the growth component of maize at screen house}

All the bioherbicide treatments determined a significantly higher growth rate on the following parameters: plant height $(\mathrm{cm})$, leaf area index, stem diameter $(\mathrm{cm})$, emergence of maize when compared to the chemical treated herbicides and weedy cheek (Tables 1 and 2). Moreover, $\mathrm{BH} 4$ provided the highest growth rate on the above tested parameters on maize compared to other treatments throughout the sampling period, whereas the least growth parameters of maize tested was recorded in the weedy check.

At 30 DAT and harvest, the fresh weight of shoot obtained from maize treated with formulation from $\mathrm{BH} 4$ were $54.34 \pm 3.14 \mathrm{~g}$ and $172.73 \pm 5.01 \mathrm{~g}$ respectively, compared to weed check that had $25.39 \pm 2.11 \mathrm{~g}$ and 96.21 $\pm 3.31 \mathrm{~g}$ at $30 \mathrm{DAT}$ and harvest respectively; the dry weight of shoot treated with the same formulation had values of

Table 1. The growth parameters of maize after application of various treatments

\begin{tabular}{|c|c|c|c|c|c|c|c|c|}
\hline \multirow{2}{*}{ Treatments } & \multicolumn{2}{|c|}{ Fresh weight of shoot $(\mathrm{g})$} & \multicolumn{2}{|c|}{ Fresh weight of root $(\mathrm{g})$} & \multicolumn{2}{|c|}{ Dry weight of shoot $(\mathrm{g})$} & \multicolumn{2}{|c|}{ Dry weight of root $(\mathrm{g})$} \\
\hline & $30 \mathrm{DAT}$ & At harvest & 30DAT & At harvest & $30 \mathrm{DAT}$ & At harvest & $30 \mathrm{DAT}$ & At harvest \\
\hline $\mathrm{BH} 1$ & $35.60 \pm 1.88^{c}$ & $126.73 \pm 5.61^{\mathrm{c}}$ & $16.93 \pm 2.03^{c}$ & $68.34 \pm 2.15^{c}$ & $17.67 \pm 2.01^{\mathrm{c}}$ & $42.38 \pm 3.18^{c}$ & $6.68 \pm 0.62^{c}$ & $16.21 \pm 1.09^{c}$ \\
\hline $\mathrm{BH} 2$ & $46.79 \pm 2.13^{b}$ & $158.39 \pm 4.04^{\mathrm{b}}$ & $20.76 \pm 2.11^{\mathrm{b}}$ & $34.01 \pm 2.10^{\mathrm{b}}$ & $19.78 \pm 1.37^{\mathrm{b}}$ & $52.11 \pm 2.03^{b}$ & $8.69 \pm 0.91^{b}$ & $20.67 \pm 2.16^{b}$ \\
\hline $\mathrm{BH} 3$ & $37.23 \pm 2.67^{c}$ & $136.32 \pm 4.93^{c}$ & $17.11 \pm 1.23^{\mathrm{c}}$ & $70.27 \pm 4.04^{c}$ & $18.17 \pm 1.13^{c}$ & $46.38 \pm 1.63^{c}$ & $8.01 \pm 0.58^{c}$ & $18.67 \pm 1.27^{\mathrm{c}}$ \\
\hline $\mathrm{BH} 4$ & $54.34 \pm 3.14^{\mathrm{a}}$ & $172.73 \pm 5.01^{\mathrm{a}}$ & $25.23 \pm 3.76^{a}$ & $89.63 \pm 4.23^{\mathrm{a}}$ & $20.67 \pm 1.12^{\mathrm{a}}$ & $60.78 \pm 3.93^{a}$ & $9.32 \pm 1.07^{\mathrm{a}}$ & $22.69 \pm 1.91^{\mathrm{a}}$ \\
\hline $\mathrm{BH} 5$ & $33.63 \pm 2.26^{c}$ & $111.29 \pm 3.45^{c}$ & $16.01 \pm 1.87^{c}$ & $65.52 \pm 3.40^{c}$ & $16.34 \pm 2.30^{c}$ & $39.78 \pm 2.54^{c}$ & $6.12 \pm 1.02^{c}$ & $15.98 \pm 1.23^{c}$ \\
\hline BH6 & $42.87 \pm 2.93^{b}$ & $143.28 \pm 3.13^{\mathrm{b}}$ & $17.36 \pm 1.95^{\mathrm{b}}$ & $76.13 \pm 4.31^{\mathrm{b}}$ & $19.23 \pm 2.05^{\mathrm{b}}$ & $48.21 \pm 2.79^{b}$ & $8.13 \pm 0.99^{\mathrm{b}}$ & $19.66 \pm 1.65^{b}$ \\
\hline $\mathrm{CC}$ & $30.67 \pm 2.23^{d}$ & $101.93 \pm 4.39^{d}$ & $15.98 \pm 1.45^{\mathrm{e}}$ & $60.32 \pm 3.88^{e}$ & $13.13 \pm 1.70^{\mathrm{e}}$ & $35.96 \pm 2.13^{\mathrm{e}}$ & $6.01 \pm 0.56^{\mathrm{e}}$ & $15.06 \pm 1.48^{\mathrm{e}}$ \\
\hline $\begin{array}{l}\text { Weedy } \\
\text { check }\end{array}$ & $25.39 \pm 2.11^{\mathrm{e}}$ & $96.21 \pm 3.31^{\mathrm{e}}$ & $13.93 \pm 2.67^{\mathrm{e}}$ & $43.27 \pm 3.46^{e}$ & $10.96 \pm 1.92^{\mathrm{e}}$ & $30.78 \pm 2.15^{\mathrm{e}}$ & $4.29 \pm 0.53^{\mathrm{e}}$ & $13.73 \pm 2.08^{\mathrm{e}}$ \\
\hline
\end{tabular}

${ }^{a}$ Average of the 3 replications. Mean separated by DMRT and column represented with the same letter are not significantly different at $5 \%$ level of significant. DAT $=$ Days after planting; $\mathrm{CC}=$ chemical control, Control $=$ Pestal granules without any fungus and adjuvant, $\mathrm{BH}=32 \mathrm{~g}$ of semolina $+6 \mathrm{~g} \mathrm{kaolin}+20 \mathrm{~mL}$ of glycerol + wild strain of Lasiodiplodia pseudotheobromae (WLp) + glucose + sucrose + fructose + dextrose + lactose sugar + peptone, $\mathrm{BH} 2=32 \mathrm{~g}$ of semolina $+6 \mathrm{~g}$ kaolin $+20 \mathrm{~mL}$ of glycerol + mutant strain of Lasiodiplodia pseudotheobromae $(\mathrm{Lp} 60), \mathrm{BH} 3=32 \mathrm{~g}$ of semolina $+6 \mathrm{~g}$ kaolin + Lasiodiplodia pseudotheobromae $(\mathrm{Lp} 30)+$ glucose + sucrose + fructose + dextrose + lactose sugar + peptone, $\mathrm{BH} 4=32 \mathrm{~g}$ of semolina $+6 \mathrm{~g}$ kaolin $+20 \mathrm{~mL}$ of glycerol + mutant strain of Lasiodiplodia pseudotheobromae $(\mathrm{Lp} 90)+$ glucose + sucrose + fructose + dextrose + lactose sugar + peptone, $\mathrm{BH} 5=32 \mathrm{~g}$ of semolina $+6 \mathrm{~g}$ kaolin $+20 \mathrm{~mL}$ of glycerol + wild strain of Lasiodiplodia psendotheobromae (WLp), $\mathrm{BH} 6=32 \mathrm{~g}$ of semolina $+6 \mathrm{~g}$ kaolin $+20 \mathrm{~mL}$ of glycerol + mutant of Lasiodiplodia pseudotheobromae (Lp30).

Table 2. The growth components of maize plant after application of various treatments

\begin{tabular}{|c|c|c|c|c|c|c|c|}
\hline \multirow[t]{2}{*}{ Treatment } & \multicolumn{2}{|c|}{$\begin{array}{l}\text { Plant height } \\
(\mathrm{cm})\end{array}$} & \multicolumn{2}{|c|}{$\begin{array}{c}\text { Leaf area } \\
\text { index } \\
\end{array}$} & \multicolumn{2}{|c|}{$\begin{array}{c}\text { Stem diameter } \\
(\mathrm{cm}) \\
\end{array}$} & \multirow{2}{*}{$\begin{array}{c}\begin{array}{c}\text { Emergence of } \\
\text { maize }\end{array} \\
\text { Days }\end{array}$} \\
\hline & $30 \mathrm{DAT}$ & At harvest & $30 \mathrm{DAT}$ & At harvest & $30 \mathrm{DAT}$ & At harvest & \\
\hline $\mathrm{BH} 1$ & $36.38 \pm 2.09^{c}$ & $232.11 \pm 6.15^{c}$ & $3.35 \pm 0.30^{c}$ & $3.65 \pm 1.01^{c}$ & $1.32 \pm 0.11^{\mathrm{b}}$ & $1.65 \pm 0.21^{b}$ & $8.00 \pm 0.32^{b}$ \\
\hline $\mathrm{BH} 2$ & $46.32 \pm 2.13^{b}$ & $286.74 \pm 4.38^{b}$ & $3.37 \pm 0.80^{\mathrm{b}}$ & $3.72 \pm 0.06^{\mathrm{b}}$ & $1.35 \pm 0.23^{\mathrm{a}}$ & $2.00 \pm 0.11^{\mathrm{a}}$ & $7.00 \pm 0.43^{\mathrm{a}}$ \\
\hline $\mathrm{BH} 3$ & $39.75 \pm 1.91^{c}$ & $253.83 \pm 4.22^{c}$ & $3.90 \pm 0.31^{\mathrm{c}}$ & $4.00 \pm 0.67^{\mathrm{c}}$ & $1.21 \pm 0.12^{c}$ & $1.87 \pm 0.60^{c}$ & $8.00 \pm 0.17^{b}$ \\
\hline BH4 & $49.67 \pm 1.30^{\mathrm{a}}$ & $299.35 \pm 5.61^{a}$ & $4.01 \pm 0.26^{a}$ & $4.36 \pm 1.50^{\mathrm{a}}$ & $1.38 \pm 0.51^{\mathrm{a}}$ & $2.15 \pm 0.80^{\mathrm{a}}$ & $7.00 \pm 1.02^{\mathrm{a}}$ \\
\hline $\mathrm{BH} 5$ & $43.82 \pm 1.52^{c}$ & $219.36 \pm 3.29^{c}$ & $3.23 \pm 0.56^{c}$ & $3.43 \pm 0.61^{c}$ & $1.20 \pm 0.90^{c}$ & $1.48 \pm 0.36^{c}$ & $8.00 \pm 0.33^{b}$ \\
\hline BH6 & $40.21 \pm 1.33^{b}$ & $260.86 \pm 4.34^{b}$ & $3.43 \pm 0.94^{b}$ & $3.86 \pm 0.17^{b}$ & $1.34 \pm 0.22^{\mathrm{a}}$ & $1.93 \pm 0.14^{\mathrm{a}}$ & $7.00 \pm 0.88^{\mathrm{a}}$ \\
\hline $\mathrm{CC}$ & $33.84 \pm 2.13^{\mathrm{d}}$ & $210.34 \pm 3.41^{\mathrm{d}}$ & $3.12 \pm 0.61^{\mathrm{d}}$ & $3.21 \pm 0.30^{\mathrm{d}}$ & $1.13 \pm 0.15^{\mathrm{d}}$ & $1.35 \pm 0.32^{\mathrm{d}}$ & $9.00 \pm 1.00^{c}$ \\
\hline Weedy check & $30.37 \pm 1.56^{\mathrm{e}}$ & $198.86 \pm 3.40^{\mathrm{e}}$ & $3.01 \pm 0.85^{\mathrm{e}}$ & $3.09 \pm 0.12^{\mathrm{e}}$ & $1.07 \pm 0.05^{\mathrm{e}}$ & $1.26 \pm 0.05^{\mathrm{e}}$ & $10.00 \pm 0.18^{\mathrm{d}}$ \\
\hline
\end{tabular}

aAverage of the 3 replications. Mean separated by DMRT and column represented with the same letter are not significantly different at $5 \%$ level of significant. DAT $=$ Days after planting; $\mathrm{CC}=$ chemical control,Control $=$ Pestal granules without any fungus and adjuvant, $\mathrm{BH} 1=32 \mathrm{~g}$ of semolina $+6 \mathrm{~g}$ kaolin $+20 \mathrm{~mL}$ of glycerol + wild strain of Lasiodiplodia psendotheobromae (WLp) + glucose + sucrose + fructose + dextrose + lactose sugar + peptone, $\mathrm{BH} 2=32 \mathrm{~g}$ of semolina $+6 \mathrm{~g}$ kaolin $+20 \mathrm{~mL}$ of glycerol + mutant strain of Lasiodiplodia pseudotheobromae $(\mathrm{Lp} 60), \mathrm{BH} 3=32 \mathrm{~g}$ of semolina $+6 \mathrm{~g}$ kaolin + Lasiodiplodia pseudotheobromae $(\mathrm{Lp} 30)+$ glucose + sucrose + fructose + dextrose + lactose sugar + peptone, $\mathrm{BH} 4=32 \mathrm{~g}$ of semolina $+6 \mathrm{~g}$ kaolin $+20 \mathrm{~mL}$ of glycerol + mutant strain of Lasiodiplodia pseudotheobromae (Lp 90$)+$ glucose + sucrose + fructose + dextrose + lactose sugar + peptone, $\mathrm{BH} 5=32 \mathrm{~g}$ of semolina $+6 \mathrm{~g}$ kaolin $+20 \mathrm{~mL}$ of glycerol + wild strain of Lasiodiplodia pseudotheobromae (WLp), BH6=32 g of semolina $+6 \mathrm{~g}$ kaolin $+20 \mathrm{~mL}$ of glycerol + mutant of Lasiodiplodia pseudotheobromae (Lp30). 
134

$20.67 \pm 1.2 \mathrm{~g}$ and $60.78 \pm 3.93 \mathrm{~g}$ respectively, compared to the weed check that had $10.96 \pm 1.92 \mathrm{~g}$ and $30.78 \pm 2.15 \mathrm{~g}$ at 30 DAT and harvest (Table 1).

Similarly, the dry weight of root obtained from maize treated with formulation from BH4 were 30 DAT $(25.23 \pm$ $3.7 \mathrm{~g})$ and harvest $(89.63 \pm 4.23 \mathrm{~g})$ respectively compared to weed check that had values of $13.93 \pm 2.67 \mathrm{~g}$ and $43.27 \pm 3.46$ $\mathrm{g}$ at 30 DAT and harvest respectively, while the dry weight of root treated with the same formulation had values of $9.32 \pm$ $1.07 \mathrm{~g}$ and $22.69 \pm 1.91 \mathrm{~g}$ respectively, compared to the weed check that had $4.29 \pm 0.53 \mathrm{~g}$ and $13.73 \pm 2.08 \mathrm{~g}$ respectively at 30 DAT and harvest (Table 1).

Moreover, the following data were obtained from the growth parameter of maize treated with formulation from BH4 and weed check. At 30 DAT and harvest time the plant heights obtained were $49.67 \pm 1.30 \mathrm{~cm}$ and $299.35 \pm 5.61 \mathrm{~cm}$ respectively, while the following values were obtained for weed check: $30.37 \pm 1.56 \mathrm{~cm}$ and $198.86 \pm 3.40 \mathrm{~cm}$ respectively at 30 DAT and harvest (Table 2). Also, at 30 DAT and harvest the leaf area index obtained were $4.01 \pm 0.26$ and $4.36 \pm 1.50$ respectively for $\mathrm{BH} 4$ treated maize, while the following values were obtained for the weed check with $3.01 \pm 0.85$ and $3.09 \pm$ 0.12 respectively at $30 \mathrm{DAT}$ and harvest. The values obtained for stem diameter of $\mathrm{BH} 4$ treated maize at $30 \mathrm{DAT}$ and harvest were $1.38 \pm 0.51 \mathrm{~cm}$ and $2.15 \pm 0.80 \mathrm{~cm}$, while the following values were obtained for the weed check with $1.07 \pm$ $0.05 \mathrm{~cm}$ and $1.26 \pm 0.05 \mathrm{~cm}$ respectively at 30 DAT and harvest. Moreover, $\mathrm{BH} 4$ treated maize emerged on the $7^{\text {th }}$ day after planting, while the weed check emerged on the $10^{\text {th }}$ day (Table 2).

In addition, $\mathrm{BH} 4$, out of all the formulated bioherbicides, determined significant effects on all the weed parameters of maize plant. However, the same formulation had a significant effect on the growth components of maize compared to the chemical treated herbicides and weedy cheek (Table 3). At 30 DAT and harvest, the weed control per treated pot from formulation $\mathrm{BH} 4$ were $3.01 \pm 0.12$ and $4.15 \pm 0.04$ respectively, compared to weed check that had $12.35 \pm 1.01$ and $19.21 \pm 1.67$ at 30 DAT and harvest respectively, while the dry weight of weeds treated with $\mathrm{BH} 4$ had values of $0.02 \pm$ $0.01 \mathrm{~g}$ and $0.05 \pm 0.01 \mathrm{~g}$ respectively compared to the weed check that had $1.89 \pm 0.90 \mathrm{~g}$ and $2.3 \pm 0.16 \mathrm{~g}$ respectively at 30 DAT and harvest (Table 3). Also, the weed control efficiency obtained from maize treated with formulation $\mathrm{BH} 4$ at 30 DAT and harvest were $0.73 \pm 3.10 \%$ and $72.45 \pm 3.70 \%$ respectively compared to weed check that had $0 \%$ weed control efficiency at 30 DAT and harvest respectively (Table 3).

The cost of production of the various formulated bioherbicides in comparison with herbicides used in the screen house

It was observed that the cost of production of the various bioherbicides formulation was far cheaper when compared to the chemical herbicide used, $\mathrm{BH} 4$ being the cheapest, followed by $\mathrm{BH} 2, \mathrm{BH} 6, \mathrm{BH} 3, \mathrm{BH} 5, \mathrm{BH} 1$, glyphosate and weedy check. The control treatment contained only the carrier, which is containing semolina only. $\mathrm{BH} 4$ was found to be the best formulation out of all the bioherbicides and its cost of production was $\$ 0.33$, while the cost of production of a bottle of glyphosate was $\$ 3.17$. Moreover, the cost of production of the control treatment which contained only the carrier made of semolina only was found to be $\$ 0.33$ (Table 4).

\section{Effect of the different formulated bioherbicides on the yield component of maize}

All the bioherbicide treatments gave significantly higher yield component on the following parameters: tasselling, number of cobs, day of silking, number of ears, number of grain/cob, weight of 100 grains, number of cob, weight of cob, and length of cob from maize when compared to the chemical treated herbicides and weedy cheek (Table 5). Moreover, $\mathrm{BH} 4$ gave the highest growth rate on the above tested parameters on maize compared to other treatments throughout the sampling period, whereas the significantly least yield components of maize tested was recorded in the weedy check. The following parameters were obtained from the yield of maize when formulation $\mathrm{BH} 4$ was applied. It took 50 days for plants to tassel when $\mathrm{BH} 4$ was applied, while it took 60 days for the weed check. Similarly, silking took 55 days when BH4 was applied, while it took 68 days in weed check. The number of cobs/plant for BH4 was $1.89 \pm 0.25$ compared to weed check that had $1.21 \pm 0.08$. Also, the number of ears/plant for BH4 was $1.33 \pm 0.02$ compared to weed check that had $1.10 \pm$ 0.01 . Moreover, the values obtained for $100 \mathrm{~g}$ weight of cobs, number of grain/cob and cob length $(\mathrm{cm})$ were $23.67 \pm 4.23$, $1.89 \pm 0.06 \mathrm{~g}$ and $17.59 \pm 2.01 \mathrm{~cm}$, compared to weed check that had the following values respectively $6.68 \pm 2.12,1.21 \pm$ $0.67 \mathrm{~g}$ and $10.23 \pm 2.43 \mathrm{~cm}$ (Table 5).

Table 3. The weed parameters of maize plant after application of various treatments

\begin{tabular}{|c|c|c|c|c|c|c|}
\hline \multirow{2}{*}{ Treatments } & \multicolumn{2}{|c|}{ Weed control per pot } & \multicolumn{2}{|c|}{ Weed dry weight (g) } & \multicolumn{2}{|c|}{ Weed control efficiency (\%) } \\
\hline & $30 \mathrm{DAT}$ & At harvest & $30 \mathrm{DAT}$ & At harvest & $30 \mathrm{DAT}$ & At harvest \\
\hline $\mathrm{BH} 1$ & $5.32 \pm 0.23^{c}$ & $7.70 \pm 1.01^{\mathrm{c}}$ & $0.05 \pm 0.01^{\mathrm{c}}$ & $0.75 \pm 0.26^{c}$ & $29.82 \pm 2.33^{\mathrm{e}}$ & $31.67 \pm 2.63^{f}$ \\
\hline $\mathrm{BH} 2$ & $3.06 \pm 0.10^{\mathrm{b}}$ & $6.21 \pm 0.09^{\mathrm{b}}$ & $0.03 \pm 0.01^{\mathrm{b}}$ & $0.06 \pm 0.05^{b}$ & $42.75 \pm 3.17^{\mathrm{b}}$ & $51.23 \pm 2.54^{c}$ \\
\hline $\mathrm{BH} 3$ & $4.02 \pm 0.05^{c}$ & $6.78 \pm 0.82^{c}$ & $0.04 \pm 0.02^{c}$ & $0.07 \pm 0.02^{\mathrm{c}}$ & $33.29 \pm 2.72^{\mathrm{d}}$ & $40.23 \pm 3.14^{\mathrm{d}}$ \\
\hline BH4 & $3.01 \pm 0.12^{\mathrm{a}}$ & $4.15 \pm 0.04^{a}$ & $0.02 \pm 0.01^{\mathrm{a}}$ & $0.05 \pm 0.01^{\mathrm{a}}$ & $50.73 \pm 3.10^{\mathrm{a}}$ & $72.45 \pm 3.70^{a}$ \\
\hline $\mathrm{BH} 5$ & $6.16 \pm 0.25^{c}$ & $7.76 \pm 1.03^{c}$ & $0.06 \pm 0.02^{c}$ & $0.87 \pm 0.31^{\mathrm{c}}$ & $20.36 \pm 2.34^{f}$ & $33.13 \pm 2.41^{\mathrm{e}}$ \\
\hline BH6 & $3.06 \pm 0.09^{\mathrm{b}}$ & $6.83 \pm 0.06^{\mathrm{b}}$ & $0.03 \pm 0.01^{\mathrm{b}}$ & $0.06 \pm 0.02^{b}$ & $40.13 \pm 3.45^{c}$ & $52.31 \pm 3.10^{\mathrm{b}}$ \\
\hline $\mathrm{CC}$ & $8.37 \pm 1.00^{\mathrm{d}}$ & $12.67 \pm 1.20^{\mathrm{d}}$ & $0.91 \pm 0.11^{\mathrm{d}}$ & $1.07 \pm 0.49^{d}$ & $7.32 \pm 1.04^{\mathrm{g}}$ & $10.93 \pm 1.13^{\mathrm{g}}$ \\
\hline Weedy check & $12.35 \pm 1.01^{\mathrm{e}}$ & $19.21 \pm 1.67$ & $1.89 \pm 0.90^{\mathrm{e}}$ & $2.3 \pm 0.164^{\mathrm{e}}$ & $0.00 \pm 0.00^{\mathrm{h}}$ & $0.00 \pm 0.00^{\mathrm{h}}$ \\
\hline
\end{tabular}

${ }^{a}$ Average of the 3 replications. Mean separated by DMRT and column represented with the same letter are not significantly different at $5 \%$ level of significant. DAT $=$ Days after planting; $\mathrm{CC}=$ chemical control,Control $=$ Pestal granules without any fungus and adjuvant, $\mathrm{BH}=32 \mathrm{~g}$ of semolina $+6 \mathrm{~g}$ kaolin $+20 \mathrm{~mL}$ of glycerol + wild strain of Lasiodiplodia pseudotheobromae (WLp) + glucose + sucrose + fructose + dextrose + lactose sugar + peptone, $\mathrm{BH} 2=32 \mathrm{~g}$ of semolina $+6 \mathrm{~g}$ kaolin $+20 \mathrm{~mL}$ of glycerol + mutant strain of Lasiodiplodia psendotheobromae $(\mathrm{Lp} 60), \mathrm{BH} 3=32 \mathrm{~g}$ of semolina $+6 \mathrm{~g}$ kaolin + Lasiodiplodia pseudotheobromae $(\mathrm{Lp} 30)+$ glucose + sucrose + fructose + dextrose + lactose sugar + peptone, BH4 $=32 \mathrm{~g}$ of semolina $+6 \mathrm{~g}$ kaolin $+20 \mathrm{~mL}$ of glycerol + mutant strain of Lasiodiplodia pseudotheobromae (Lp 90$)+$ glucose + sucrose + fructose + dextrose + lactose sugar + peptone, $\mathrm{BH} 5=32 \mathrm{~g}$ of semolina $+6 \mathrm{~g}$ kaolin $+20 \mathrm{~mL}$ of glycerol + wild strain of Lasiodiplodia pseudotheobromae (WLp), $\mathrm{BH} 6=32 \mathrm{~g}$ of semolina $+6 \mathrm{~g}$ kaolin $+20 \mathrm{~mL}$ of glycerol + mutant of Lasiodiplodia pseudotheobromae (Lp30). 
Table 5. The effect of various formulations from Lasiodiplodia psedotheobromae on yield component of maize

\begin{tabular}{|c|c|c|c|c|c|c|c|}
\hline Treatments & $\begin{array}{c}\text { Days to } \\
\text { tasseling }\end{array}$ & $\begin{array}{c}\text { No of } \\
\text { cobs/plant }\end{array}$ & $\begin{array}{c}\text { Days to } \\
\text { silking }\end{array}$ & $\begin{array}{c}\text { No of ears/ } \\
\text { plant }\end{array}$ & $\begin{array}{c}100 \text { grains } \\
\text { weight of cobs }\end{array}$ & $\begin{array}{c}\text { No of grain/ } \\
\text { cob }\end{array}$ & $\begin{array}{c}\text { Cob length } \\
(\mathrm{cm})\end{array}$ \\
\hline $\mathrm{BH} 1$ & $56.00 \pm 2.01^{\mathrm{abc}}$ & $1.43 \pm 0.03^{\text {ns }}$ & $58.00 \pm 2.46^{\mathrm{b}}$ & $1.32 \pm 0.78^{\mathrm{ns}}$ & $16.43 \pm 0.03^{\mathrm{e}}$ & $1.43 \pm 0.24^{\mathrm{ns}}$ & $13.32 \pm 2.46^{\mathrm{e}}$ \\
\hline $\mathrm{BH} 2$ & $52.00 \pm 2.14^{\mathrm{cd}}$ & $1.76 \pm 0.22^{\mathrm{ns}}$ & $55.00 \pm 2.18^{b}$ & $1.33 \pm 0.45^{\mathrm{ns}}$ & $21.86 \pm 3.21^{\mathrm{b}}$ & $1.76 \pm 0.38^{\mathrm{ns}}$ & $15.89 \pm 2.35^{b}$ \\
\hline $\mathrm{BH} 3$ & $55.00 \pm 2.10^{\mathrm{abcd}}$ & $1.53 \pm 0.24^{\mathrm{ns}}$ & $57.00 \pm 3.11^{\mathrm{b}}$ & $1.22 \pm 0.23^{\mathrm{ns}}$ & $17.36 \pm 3.02^{\mathrm{d}}$ & $1.53 \pm 0.21^{\mathrm{ns}}$ & $14.78 \pm 2.21^{\mathrm{d}}$ \\
\hline BH4 & $50.00 \pm 3.02^{\mathrm{d}}$ & $1.89 \pm 0.25^{\mathrm{ns}}$ & $55.00 \pm 4.01^{b}$ & $1.33 \pm 0.02^{\mathrm{ns}}$ & $23.67 \pm 4.23^{\mathrm{a}}$ & $1.89 \pm 0.06^{\mathrm{ns}}$ & $17.59 \pm 2.01^{\mathrm{a}}$ \\
\hline $\mathrm{BH} 5$ & $56.00 \pm 1.97^{\mathrm{abc}}$ & $1.38 \pm 0.2^{\mathrm{ns}}$ & $58.00 \pm 2.59^{\mathrm{b}}$ & $1.14 \pm 0.35^{\mathrm{ns}}$ & $15.32 \pm 3.17^{\mathrm{f}}$ & $1.38 \pm 0.26^{\mathrm{ns}}$ & $13.1 \pm 2.53^{f}$ \\
\hline BH6 & $53.00 \pm 2.06^{\mathrm{bcd}}$ & $1.63 \pm 0.03^{\mathrm{ns}}$ & $56.00 \pm 2.62^{b}$ & $1.22 \pm 0.68^{\mathrm{ns}}$ & $19.67 \pm 3.19^{c}$ & $1.63 \pm 0.32^{\mathrm{ns}}$ & $14.98 \pm 2.21^{\mathrm{c}}$ \\
\hline $\begin{array}{c}\text { Chemical } \\
\text { control }\end{array}$ & $58.00 \pm 4.05^{\mathrm{ab}}$ & $1.41 \pm 0.06^{\mathrm{ns}}$ & $65.00 \pm 3.00 \mathrm{a}$ & $1.11 \pm 0.76^{\mathrm{ns}}$ & $12.39 \pm 2.53^{\mathrm{g}}$ & $1.41 \pm 0.43^{\mathrm{ns}}$ & $12.97 \pm 2.56^{\mathrm{g}}$ \\
\hline Weedy check & $60.00 \pm 3.16^{\mathrm{a}}$ & $1.21 \pm 0.08^{\mathrm{ns}}$ & $68.00 \pm 2.98^{\mathrm{a}}$ & $1.10 \pm 0.01^{\mathrm{ns}}$ & $6.68 \pm 2.12^{\mathrm{h}}$ & $1.21 \pm 0.67^{\mathrm{ns}}$ & $10.23 \pm 2.43^{\mathrm{h}}$ \\
\hline
\end{tabular}

${ }^{2}$ Average of the 3 replications. Mean separated by DMRT and column represented with the same letter are not significantly different at $5 \%$ level of significant. DAT $=$

Days after planting; $\mathrm{ns}=$ non-significant; $\mathrm{CC}=$ chemical control,Control $=$ Pestal granules without any fungus and adjuvant, $\mathrm{BH} 1=32 \mathrm{~g}$ of semolina $+6 \mathrm{~g}$ kaolin +20 $\mathrm{mL}$ of glycerol + wild strain of Lasiodiplodia psendotheobromae (WLp) + glucose + sucrose + fructose + dextrose + lactose sugar + peptone, $\mathrm{BH} 2=32 \mathrm{~g}$ of semolina $+6 \mathrm{~g}$ kaolin $+20 \mathrm{~mL}$ of glycerol + mutant strain of Lasiodiplodia pseudotheobromae $(\mathrm{Lp} 60), \mathrm{BH} 3=32 \mathrm{~g}$ of semolina $+6 \mathrm{~g}$ kaolin + Lasiodiplodia pseudotheobromae $(\mathrm{Lp} 30)+$ glucose + sucrose + fructose + dextrose + lactose sugar + peptone, BH4 $=32 \mathrm{~g}$ of semolina $+6 \mathrm{~g}$ kaolin $+20 \mathrm{~mL}$ of glycerol + mutant strain of Lasiodiplodia pseudotheobromae $(\mathrm{Lp} 90)+$ glucose + sucrose + fructose + dextrose + lactose sugar + peptone, $\mathrm{BH} 5=32 \mathrm{~g}$ of semolina $+6 \mathrm{~g}$ kaolin $+20 \mathrm{~mL}$ of glycerol + wild strain of Lasiodiplodia pseudotheobromae (WLp), BH6=32 g of semolina $+6 \mathrm{~g}$ kaolin $+20 \mathrm{~mL}$ of glycerol + mutant of Lasiodiplodia pseudotheobromae (Lp30).

Table 4. Cost of production of each treatment used for the control of weed in maize culture

\begin{tabular}{cc}
\hline Treatments & Cost of production $(\$)$ \\
\hline BH1 & $0.43 \pm 0.25^{\mathrm{b}}$ \\
BH2 & $0.38 \pm 0.16^{\mathrm{b}}$ \\
BH3 & $0.41 \pm 0.09^{\mathrm{b}}$ \\
BH4 & $0.33 \pm 0.16^{\mathrm{b}}$ \\
BH5 & $0.44 \pm 0.05^{\mathrm{b}}$ \\
BH6 & $0.40 \pm 0.05^{\mathrm{b}}$ \\
Weedy check & $3.17 \pm 0.38^{\mathrm{a}}$ \\
CC & $0.32 \pm 0.12^{\mathrm{b}}$ \\
\hline
\end{tabular}

$\mathrm{CC}=$ chemical control; weedy check (control) containing only carrier without any bioactive carrier and adjuvants, $\mathrm{BH}=32 \mathrm{~g}$ of semolina $+6 \mathrm{~g}$ kaolin $+20 \mathrm{~mL}$ of glycerol + wild strain of Lasiodiplodia pseudotheobromae (WLp) + glucose + sucrose + fructose + dextrose + lactose sugar + peptone, $\mathrm{BH} 2=32 \mathrm{~g}$ of semolina + $6 \mathrm{~g}$ kaolin $+20 \mathrm{~mL}$ of glycerol + mutant strain of Lasiodiplodia pseudotheobromae (Lp 60), BH3 = $32 \mathrm{~g}$ of semolina $+6 \mathrm{~g}$ kaolin + Lasiodiplodia pseudotheobromae (Lp 30) + glucose + sucrose + fructose + dextrose + lactose sugar + peptone, $\mathrm{BH}$ $=32 \mathrm{~g}$ of semolina $+6 \mathrm{~g}$ kaolin $+20 \mathrm{~mL}$ of glycerol + mutant strain of Lasiodiplodia pseudotheobromae $(\mathrm{Lp} 90)+$ glucose + sucrose + fructose + dextrose + lactose sugar + peptone, $\mathrm{BH} 5=32 \mathrm{~g}$ of semolina $+6 \mathrm{~g} \mathrm{kaolin}+20 \mathrm{~mL}$ of glycerol + wild strain of Lasiodiplodia psendotheobromae (WLp), BH6=32 g of semolina $+6 \mathrm{~g}$ kaolin $+20 \mathrm{~mL}$ of glycerol + mutant of Lasiodiplodia pseudotheobromae (Lp30).

\section{Discussion}

Due to the development of herbicide resistance and a trend towards a chemically free environment, biological control using plant pathogens (bioherbicides) has been considered (Hoagland, 2007). The phytotoxic metabolite from Lasiodiplodia pseudotheobromae used during the current study had no adverse effect on the tested crop, but showed a bioherbicidal effect on all the tested weeds. Some authors have also reported similar results from the use of fungal phytotoxic metabolite (Evidente et al., 2003).

Plant height is one of the important growth parameters of any crop, as it determines or modifies the yield contributing characters and finally shapes the grain yield (Reddy and Reddi, 2002). It was observed that the formulated bioherbicides enhanced the plant height of the maize, out of which $\mathrm{BH} 4$ had the best height of maize, because it enhanced plant height by a better soil aeration and increased the organic carbon content of the soil compared to others (Vijayakumar et al., 2006). Variation in plant height of maize could be attributed to the various effect of treatment used for controlling weeds. These results are in line with Akhtar et al. (1998) and Hussain et al. (1998), who stated that the maximum plant height was in treated pots compared with untreated ones.

The variations in LAI (leaf area index) are an important physiological feature that determines crop yield (Evans and wardlaw, 1976). The LAI is a determinant of dry matter production, and hence increased the total dry matter production results in increased grain yield for a given variety (Yoshida, 1972). There was no significant difference in leaf area per plant among the bioherbicide treatments when compared with the control.

The production of total dry matter per unit area is the prerequisites for higher production. The amount of dry matter production depends on the effectiveness of photosynthesis of the crop, which in turn depends on large and efficient assimilating area for adequate supply of solar radiation and carbon dioxide and favourable environmental condition (Reddy and Reddi, 2002). The total yield of dry matter accumulation is the total amount of dry matter produced, less than photosynthates used for respiration. Finally, the amount of economic yield depends on the manner in which the net dry matter produced is distributed among the different parts of the plants, which will determine the magnitude of economic yield (Aron, 1972).

Fageria et al. $(1997,2006)$ reported a similar reduction in shoot dry weight of upland rice from flowering to physiological maturity, as is was observed in the current study.

The number of grain rows per cob directly affected cob weight and ultimately grain yield of maize. These results are in agreement with the results obtained by Singh and Singh (1989) and Sulewska et al. (2006), who reported that weed control practices resulted in increased number of grain rows per cob. The significant variation for 1,000-grain weight in weed control treatments was due to vigorous growth and development of maize plants, which resulted in more photosynthates assimilation in grains.

These results are in line with those of Tanveer et al. (1999), Hussain et al. (1998) and Baye and Bouchache (2007) who concluded that 1,000-grain weight were greater in various controlled treatments than in weedy check in maize. The longer the cob length, the more would be the number of grains per cob and consequently higher yield in the form of grains. The data regarding to this parameter revealed that all weeds control treatments significantly affected the cob length 
136

compared with weedy check. The significantly minimum cob length was recorded in weedy check plot. The cob length was significantly high in bioherbicides, whereas the longest was from $\mathrm{BH} 4$ treatment, which could be attributed to timely and efficiently weed control and thus, less weed competition period within the treatment, which allowed the maize plant to produce more photosynthetic material by using available nutrients. These results are similar to the findings of Singh and Singh (2003) and Stefanovic et al. (2004) who observed greater cob length in weed controlled treatments and smallest cob length in weedy check plots.

Grain yield is a function of the cumulative behaviour among various yield, influencing different components namely the number of cobs per plants, cob length, number of grains per cob and 1,000-grain weight, which showed variations by prevailing growing conditions and various crop management practices. This was mainly because of more number of grain rows per cob, number of grains per cob and 1,000-grain weight over weedy check. The lowest grain yield recorded in weedy check could be attributed to the maximum weed density which suppressed the growth and development of maize plants by competing for moisture, light and nutrients. The efficiency of various chemicals and other weed control practices in enhancing grain yield had also been observed by Stefanovic $e t$ al. (2004). The total number of grains per cob is an important yield component parameter of maize which indicated that all weed control practices significantly affected the total number grains per cob. The highest number of grains per cob in bioherbicides treated maize could be due to less weeds and consequently more photosynthesis available for plant growth and development. These results are confirmatory to Tanveer $e t$ al. (1999). They concluded that all weeds control treatments significantly increased the number of grain rows and number of grains per cob.

\section{Conclusions}

This study has provided information on the effectiveness of the local isolates of Lasiodiplodia psendotheobromae used as bioherbicide. The pasta formulation proved to be an easy and cost-effective delivery system for the tested fungal isolate and has showed a high efficacy in weed control and consequently improved maize performance under screen house conditions. Moreover, more researches on the action way, non-target effect and field trial has to be carried out in different agro-ecological area to establish the mycoherbicidal potential of $L$. pseudotheobromae in different environmental conditions.

\section{Acknowledgements}

This work was supported by Council of Scientific and Industrial Research (CSIR), New Delhi, India and The World Academy of Science (TWAS), Italy for providing fund and facilities for this research work with fellowship award number: 3240267282

\section{References}

Adetunji CO, Oloke JK (2013). Efficacy of freshly prepared pesta granular formulations from the multi-combination of wild and mutant strain of Lasiodiplodia pseudotheobromae and Pseudomonas aeruginosa. Albanian Journal of Agricultural Sciences 12(4):555-
563.

Adejumo IO, Ologhobo $\mathrm{AD}$ (2015). Effect of insecticide-treated maize on heart and liver histology of laying chickens. Journal of Biology and Nature 3:21-25.

Adejumo IO, Ologhobo AD, Adedeji IA, Ogunjimi SI (2014). Status of exposure of bio-systems to restricted aluminium phosphide pesticide in Kano State, Nigeria. International Journal of Scientific Research in Knowledge 2:306-312.

Aguyoh JN, Masiunas JB (2003). Interference of redroot pigweed (Amaranthus retroflexus) with snap beans. Weed Science 51:202207.

Akhtar M, Aslam M, Malik HN (1998). Effect of various weed control method on Maize (Zea mays L.) growth and yield in heavily populated weed fields of Islamabad, Pakistan. Sarhad Journal of Agriculture 14:345-350.

Alves A, Crous PW, Correia A, Phillips AJL (2008). Morphological and molecular data reveal cryptic speciation in Lasiodiplodia theobromae. Fungi Diversity 28:1-13.

Amini R, Alizadeh H, Yousefi A (2014). Interference between red kidneybean (Phaseolus vulgaris L.) cultivars and redroot pigweed (Amaranthus retroflexus L.). European Journal of Agronomy 60:1321.

Arnon I (1972). Crop production in dry region. In: Polwin N (Ed). Vol 1 Background and Principles. International Text Book Company Limited, 158 Buckingham Palace Road, London.

Auld BA (1991). Economic aspects of biological weed control with plant pathogens. In: TeBeest DO (Ed). Microbial control of weeds. Chapman and Hall: New York pp 262-273.

Bankole SA, Mabekoje OO (2004). Occurrence of aflatoxins and fumonisins in preharvest maize from south-western Nigeria. Food Additives and Contaminants 21(3):251-255.

Baye Y, Bouhache M (2007). Competition between silver leaf night shade (Solanum elaeagnifolium Cav.). Bulletin-DEPP / EPPO Bulletin 37:129-131.

Begoude BAD, Slippers B, Wingfield MJ, Roux J (2010). Botryosphaeriaceae associated with Terminalia catappa in Cameroon, South Africa and Madagascar. Mycological Progress 9: 101-123.

Bensch CN, Horak MJ, Peterson D (2003). Interference of redroot pigweed (Amaranthus retroflexus), Palmer Amaranth (A.palmeri), and common waterhemp (A. rudis) in soybean. Weed Science 51:37-43.

Bowers RC (1982). Commercialization of microbial biological control agents. In: Charudattan R, Walker HL (Eds). Biological Control of Weeds with Plant Pathogens, Wiley, New York. pp 157-173.

Buchanan GA, Burns ER (1971). Weed competition in cotton. II . cocklebur and redroot pigweed. Weed Science 19:580-582.

Buchanan GA, Crowley RH, Street JE, McGuire JA (1980). Competition of sicklepod (Cassia obtusifolia) and redroot pigweed (Amaranthus retroflexus) with cotton (Gossypium hirsutum). Weed Science 28:258-262.

Charudattan R (1991). The myco-herbicide approach with plant 
pathogens. In: TeBeest DO (Ed). Microbial control of weeds. Chapman and Hall, New York pp 24-57.

Connick WJ Jr, Boyette CD, Mcalpine JR (1991). Formulation of myco-herbicides using a pasta-like process. Biological Control 1:281-287.

Elzein A, Kroschel J, Muller-Stover D (2004). Optimization of storage conditions for adequate shelf-life of a Pesta formulation of Fusarium oxysporum "Foxy 2", a potential mycoherbicide for Striga: effects of temperature, granule size and water activity. Biocontrol Science and Technology 14:545-559.

Elzein A, Kroschel J, Leth V (2006). Seed treatment technology: an attractive delivery system for controlling root parasitic weed Striga with mycoherbicide. Biocontrol Science and Technology 16(1-2):3-26.

Eilenberg J, Hajer A, Lomer C (2001). Suggestions for unifying the terminology in biological control. Biocontrol 46:387-400.

Evans LT, Wardlaw IF (1976). Aspects of comparative grain yield in cereals. Advances in Agronomy 28:301-359.

Evidente A, Cabras A, Maddau L, Serra S, Andolfi A, Motta A (2003). Viridepyronone, a new antifungal 6-ubstituted 2H-pyran-2-one produced by Trichoderma viride. Journal of Agriculture and Food Chemistry 51:6957-6960.

Fageria NK, Baligar VC, Jones CA (1997). Growth and mineral nutrition of field crops (2nd Ed.). Marcel Dekker Incorporation, New York, USA.

Fageria NK, Baligar VC, Clark RB (2006). Physiology of crop production. The Haworth Press, New York, USA.

Ghanizadeh H, Lorzadeh S, Aryannia N (2014). Effect of weed interference on Zea mays: growth analysis. Weed Biological Management 14:133-137.

Heap I (2015). international survey of herbicide resistant weeds. annual report internet. Retrieved 2016 Nov 27 from http://www.weedscience.com.

Hoagland RE, Boyette CD, Abbas HK (2007). Myrothecium verrucaria isolates and formulations as bioherbicide agents for kudzu. Biocontrol Science and Technology 17:721-731.

Hussain M, Jamshaid E, Akhtar K (1998). Response of maize CV. "Golden" to different doses of some pre-emergence herbicides. Journal of Animal and Plant Science 8:41-42.

Jackson MA, Schisler DA (1995). Liquid culture production of microsclerotia of Colletotrichum truncatum for use as bioherbicidal propagules. Mycology Research 99(7):879-884.

Jackson MA, Shasha BS, Schisler DA (1996). Formulation of Colletotrichum truncatum microsclerotia for improved biocontrol of the weed Hemp Sesbania (Sesbania exaltata). Biological Control 7:107-113.

Lovell ST, Wax LM, Horak MJ, Peterson DE (1996). Imidazolinone and Sulfonylurea resistance in a biotype of common waterhemp (Amaranthus rudis). Weed Science 44:789-794.

Knezevic SZ, Weise SE, Swanton CJ (1994). Interference of redroot pigweed (Amaranthus retroflexus) in corn (Zea mays). Weed Science 42:568-573.

Knezevic SZ, Weise SF, Swanton CJ (1995). Comparison of empirical models depicting density of Amaranthus retroflexus $\mathrm{L}$, and relative leat area as predictors of yield loss in maize (Zea mays L.). Weed Research 35:207-215.

Marvel H, Sarah D (2016). Assessment of chemical contaminants in corn dough from selected corn wet milling plants in Mankessim. Asian Journal of Agriculture and Rural Development 6(6):106-118.

Maton SM, Dodo JD, Nesla RA, Ali AY (2016). Environmental impact of pesticides usage on farmlands in Nigeria. International Journal of Innovative Research \& Development 5(4):311-317.

Mehl JWM, Slippers B, Roux J, Wingfield MJ (2011). Botryosphaeriaceae associated with Pterocarpus angolensis (kiaat) in South Africa. Mycologia 103:524553.

Mirshekari B, Javanshir A, Arbat HK (2010). Interference of redroot pigweed (Amaranthus retroflexus) in green bean (Phaseolus vulgaris). Weed Biological Management 120-125.

Ofor MO, Ibeawuchi II, Oparaeke AM (2009). Crop protection problems in production of maize and Guinea corn in Northern Guinea Savanna of Nigeria and control measures. Nature and Science 7(12):8-14.

Reddy TY, Reddi GHS (2002). Principles of agronomy (3rd ed.). Kalyani Publishers, New Delhi, India pp 526.

Sheibany K, Meybodi MAB, Atri A (2009). Competitive effects of redroot pigweed (Amaranthus retroflexus) on the growth indices and yield of corn. Weed Biological Management 9:152-159.

Stefanovic LM, Milivojevic M, Husic I, Samic M, Hojka Z (2004). Selectivity of the sulfonylurea herbicide group in the crop of commercial KL maize inbred lines. Institute-ze-Kukuruz, Herboglia, Serbia and Montenegro 1:53-63.

Singh JB, Singh S (1989). Effect of 2,4-dichlorophenoxyacetic acid and maleichydrazide on growth of blue green algae (cyanobacteria) Anabaena doliolum and Anacystis nidulans. Science and Culture 55:459-460.

Singh AP, Singh PC (2003). Effect of different weed control methods on growth and yield of rabisown hybrid maize cv. Hybrid 4640. Journal of Living World 10:12-15.

Sulewska H, Koizara W, Panasiewicz K (2006). Efficiency of herbicides treatment Chwastox Turbo 340 SL a nd Dual 960 EC in maize grain weed control. Progress in Plant Protection 46:240-242.

Tanveer A, Ayub M, Ali M, Ahmed R, Ayub M (1999). Weed crop competition in maize in relation to row spacing and duration. Pakistan Journal of Biological Sciences 2:363-364.

Van Acker RC, Weise SF, Swanton CJ (1993). Influence from a mixed weed species stand on soybean (Glycine max (LL Merr.) growth. Canadian Journal of Plant Sciences 73:1293-1304.

Vijayakumar MS, Chandrasekaran RB and Thiyagarajan TM (2006). Effect of system of rice intensification (SRI) practices on yield attributes yield and water productivity of rice (Oryza sativa L.). Research Journal of Agriculture and Biological Sciences 2:236-242.

Yoshida S (1972). Physiological aspects of grain yield. Annual Review of Plant Physiology 23:437-464. 